\title{
Distribution of immune response cells in the pelvic urethra and the prepuce of rams ${ }^{1}$
}

\author{
Jorge Acosta-Dibarrat ${ }^{2 *}$, Alejandro Buendía-Jiménez. ${ }^{3}$, Edgardo Soriano-Vargas², \\ Roberto Montes de Oca-Jiménez ${ }^{2}$ and Jorge Tórtora-Pérez ${ }^{3}$
}

\begin{abstract}
Acosta-Dibarrat J., Buendía-Jimenez. A., Soriano-Vargas E., Oca-Jiménez R.M. \& Tórtora-Pérez J. 2014. Distribution of immune response cells in the pelvic urethra and the prepuce of rams. Pesquisa Veterinária Brasileira 34(3):270-276. Centro de Investigación y Estudios Avanzados en Salud Animal, Facultad de Medicina Veterinaria y Zootecnia, Universidad Autónoma del Estado de México, Km 15.5 Carretera Toluca-Atlacomulco, C.P. 50100, Toluca, Estado de Mexico, México. E-mail: jpacosta00@hotmail.com

The pathogens of the reproductive system in the male can penetrate and establish by ascending route, from to the prepuce to the urethra, accessory glands, epididymis and testicles. The aim of this paper is determine the distribution and number of cells involved in the immune response in prepuce and pelvic urethra of rams, without apparent clinical alterations in testicle, epididymis and prepuce. The distribution of some of the cells involved in the immune response at the level of the prepuce and the pelvic urethra was quantified in four one-year-old rams seronegative for $B$. ovis and $A$. seminis and without apparent lesions in the testicles, the epididymis, and the prepuce. At the moment of slaughter, samples were taken from the preputial fornix and the pelvic urethra and placed in $10 \%$ formalin and under freezing conditions. CD4, CD8, WC1, CD45R0, CD14 and CD1b cells were demonstrated by immunohistochemistry, and immunoglobulin-containing cells (ICC) of the IgA, IgG and IgM classes were demonstrated by immunofluorescence. The labeled cells present in the mucosa of both organs were counted with an image analyzer. The total number of cells was compared between both tissues and differentially between the epithelium and the connective tissue of the mucosa. Significant differences were found in the total number of CD4, CD45RO, and WC1 lymphocytes, in CD14 macrophages, and CD1b dendritic cells, with mean values being greater in the fornix than in the urethra $(\mathrm{p}<0.05)$ in all cases. Only dendritic cells were found in the prepuce. No differences were found in the number of CD8 lymphocytes between both organs. The ratio between each cell type in the connective and the intraepithelial tissues and between organs was $10 / 1$ for CD4 in the fornix ( $\mathrm{p}<0.05)$, against $7 / 1$ in the urethra $(\mathrm{p}<0.05)$, while CD8 had a $1 / 1$ distribution in both mucosae. The WC1 ratio was $5 / 1$ in both mucosae $(\mathrm{p}<0.05)$. CD45RO labeling was $19 / 1$ in the prepuce $(\mathrm{p}<0.05)$ and $1 / 1$ in the urethra. IgA-containing cells did not show differences in the total number of cells in both tissues. In the urethra, no IgG-containing cells were observed and IgM-containing cells were scarce; in contrast, both cell types were present in the prepuce, in amounts greater than in the urethra $(\mathrm{p}<0.05)$. IgA-, IgG-, and IgM-containing cells were located in both organs in the mucosal connective tissue. The presence of antigen-presenting cells, macrophages, and dendritic cells, as well as of lymphocytes CD4, CD8 TCR $\gamma \delta$ (WC1), IgA-, IgG and IgM positive cells, and CD45R0 cells suggests that both mucosae may behave as inductive and effector sites for the mucosal immune response.
\end{abstract}

INDEX TERMS: Rams, prepuce, pelvic urethra, immune response cells.

\footnotetext{
${ }^{1}$ Received on September 24, 2013.

Accepted for publication on January 21, 2014.

${ }^{2}$ Centro de Investigación y Estudios Avanzados en Salud Animal, Facultad de Medicina Veterinaria y Zootecnia, Universidad Autónoma del Estado de México, Km 15.5 Carretera Toluca-Atlacomulco, C.P. 50100,
}

Toluca, Estado de México, México. *Corresponding author: jpacosta00@ hotmail.com

${ }^{3}$ Facultad de Estudios Superiores Cuautitlán, Universidad Nacional Autónoma de México, Km 2.5 Carretera Cuautitlán-Teoloyucan, C.P. 54714, Cuautitlán Izcalli, Estado de México, México. 
RESUMO.- [Distribuição de células da resposta imune na uretra pélvica e em prepúcio de carneiros.] Os patógenos do aparelho reprodutor do macho podem penetrar e se estabelecer por via ascendente, a partir do prepúcio à uretra, glándulas anexas, epidídimo e testículos. Neste trabalho foi quantificada a distribuição de algumas das células envolvidas na resposta imune, em nível de prepúcio e uretra pélvica, em quatro carneiros de um ano de idade, sem lesões aparentes no testículo, no epidídimo e no prepúcio. No momento da eutanásia foram coletadas amostras do prepúcio e da uretra pélvica, as quais foram conservadas em formalina $10 \%$ e congeladas. De acordó com as análises de imunohistoquímica foram observadas células CD4, CD8, WC1, CD45RO, CD14 e CD1b; e por imunoflorescência foram observadas células que continham imunoglobulinas (CCI) das clases IgA, IgG e IgM. Com um analisador de imagens foi feita a contagem das células marcadas, presentes na mucosa de ambos os orgãos. Foi realizada a comparação entre o total de células entre ambos os tecidos e de forma diferencial entre os tecidos epitelial e conectivo da mucosa. Foram encontradas diferenças significativas no número total de linfócitos CD4, CD45R0 e WC1, no número de macrófagos CD14 e células dendríticas $\mathrm{CD} 1 \mathrm{~b}$, com valores de médias que foram maiores em todas as amostras coletadas do prepucio, em relação as amostras coletadas da uretra $(\mathrm{p}<0.05)$. Células dendríticas só foram encontradas no prepúcio. Não foram encontradas diferenças significativas no número de linfocitos CD8 entre ambos os orgãos. A relação entre cada tipo celular no tecido conectivo e intra-epitelial e entre os diferentes órgãos, resultou para CD4 10/1 no prepúcio ( $\mathrm{p}<0.05)$, contra $7 / 1$ na uretra $(p<0.05)$, entretanto os CD8 se distribuíram $1 / 1$ em ambas as mucosas, não sendo significativa as diferenças. Os WC1 foram observados na relação $5 / 1 \mathrm{em}$ ambas as mucosas $(\mathrm{p}<0.05)$. A célula CD45RO, no prepucio, foi observada de $19 / 1(p<0.05)$ e na uretra de $1 / 1$, não sendo um resultado significativo. As CC-IgA não mostraram diferença significativa no total de células em ambos os tecidos. $\mathrm{Na}$ uretra não foram observadas as CC-IgG, e as CC-IgM foram escassas; em contrapartida, ambos os tipos celulares foram observadas no prepucio, em quantidades menores que na uretra $(\mathrm{p}<0.05)$. As CC-IgA, IgG e IgM foram observadas em ambos os tecidos conectivos da mucosa. A presença de células apresentadoras de antígenos, macrófagoss e células dendríticas, assim como de linfócitos CD4, CD8. TCR $\gamma \delta$ (WC1), CC-IgA, IgG e IgM e células CD45RO, determinam que ambas as mucosas podem se comportar como locais de indução e promoção da resposta imune das mucosas.

TERMOS DE INDEXAÇÃO: Carneiros, prepúcio, uretra pélvica, células da resposta imune.

\section{INTRODUCTION}

Immune response cells in the male genital tract have to carry out recognition and response functions against potential pathogens, and they must also tolerate germ cells that expose extraneous antigens to the immune system (Anderson \& Pudney 1999). In contrast to the female reproductive apparatus, in which immune response cells have already been studied regarding their distribution and characteris- tics, those of the male reproductive tract have been little explored, even in humans (Moldoveanu et al. 2005).

In rams, Brucella ovis, one of the most widely studied diseases, can be experimentally reproduced by inoculating the bacterium by conjunctival, oral, intrapreputial or intravenous route (Plant et al. 1986). In contrast, in the case of $A$. seminis, the evidence points to the retrograde entry of the pathogen through the urethra, since it is frequently present in the preputial mucosa of puberal animals (Jansen 1983, Acosta-Dibarrat et al. 2006, 2007), while Tritrichomona foetus in cattle is a venereal infection, in which the first line of defense is the epithelial barrier and the normal flora of both the prepuce and the vagina (Corbeil \& BonDurant 2001).

Studies that quantify the presence of immunoglobulin-producing cells (Igs) in the reproductive organs are scarce. It has been demonstrated that $B$. ovis infection generates a strong IgA response in the secretions of the accessory glands, as well as the presence of IgA-containing cells in the ampulla of the ductus deferens. However, the changes in IgA-containing cells in the bulbourethral glands and the total IgG and IgM concentrations in the secretions were not significant (Foster et al. 1988a).

The immune response against $T$. foetus in the preputial mucosa and the penis of bulls was described by Campero et al. (1990), indicating mononuclear infiltration in both mucosae, presence of plasma cells, and an epithelium infiltrated with lymphocytes, similar to that described in the tonsils (Flower et al. 1982). These studies define the preputial and penile mucosa as inductive sites of the immune response (Campero et al. 1990).

The presence of lymphoid tissue associated with the reproductive mucosa of males would have antigen processing and immune response to potential pathogens as its main function. The aim of this study was to quantify and determine the distribution of cells involved in the immune response at the level of the prepuce and the pelvic urethra.

\section{MATERIALS AND METHODS}

\section{Animals and Sample collection}

The animals were kept during the performance of the previous examine to slaughter facilities in the FES Cuautitlán UNAM. Sampling protocols and slaughter were endorsed by the Subcommittee Institutional Animal Care Experimentation (SICUAE) of the Faculty of Veterinary Medicine, UNAM. This protocol was approved by UNAM at $20 / 06 / 2003$.

Paired samples of the prepuce were taken at the level of the fornix and the pelvic urethra from four one-year-old Pelibuey rams seronegative for $B$. ovis and A. seminis and without apparent lesions in the testicles, the epididymis, and the prepuce at the moment of slaughter. One of the samples was used in routine histopathological studies, it was fixed in $10 \%$ buffered formol solution, $\mathrm{pH}$ 7.4, embedded in paraffin, and was cut at $5 \mu \mathrm{m}$ and stained with hematoxylin and eosin (HE).

The other sample was used to obtain sections for immunohistochemical and immunofluorescence studies, it was placed in Tissue-Tek OCT-based cryopreservative (Sakura Finetec, Torrance, USA) and was frozen in liquid nitrogen, it was first placed over the vapors for $2 \mathrm{~min}$, and then it was immersed in the liquid, it was immediately withdrawn and was kept at $-80^{\circ} \mathrm{C}$ until processing. Four consecutive sections of $4 \mu \mathrm{m}$ in thickness and approximately one square centimeter in area were cut from these 
samples using a microtome and were mounted on slides treated with poly-L-Lysine (Sigma Chemical Co, St. Louis, USA) and were fixed with acetone for 10 minutes. One of the sections was used as negative control and the three remaining sections were used for the various marker antibodies; in all cases, a prepuce section was included as positive control, on which positive labeling for the three immunoglobulin-containing cells (IgCC) and for all monoclonal lymphocytes assayed in this study, CD4, CD8, CD45R0, WC1, CD14 and CD1b, had been previously demonstrated.

Inmunofluorescence (IF) for the detection of positive IgA-, IgG-, and IgM-containing cells

Tissue Igs were removed by placing the slides in PBS all night, nonspecific blockade with $1 \%$ BSA was carried out subsequently for 1 hour at room temperature, and three five-minute washings with PBS were performed. The sections were incubated for one hour at $37^{\circ} \mathrm{C}$ with anti-IgA, anti-IgG, and anti-ovine IgM primary antibodies prepared in rabbit, diluted in PBS with 1\% BSA. The source of monoclonal antibodies and the dilutions used are shown in Table 1 . The slides were washed and incubated for one hour at $37^{\circ} \mathrm{C}$ with TRICT-conjugated anti-rabbit IgG secondary antibody (Sigma-Aldrich, St Louis, USA) in a 1:30 dilution in 10\% goat serum and 1\% BSA. Finally, they were washed again three times for five minutes and were mounted in glycerine for observation. The primary antibody was replaced with PBS in the slide's control section, and the technique previously described was then followed. The control section was included in face of the possibility of nonspecific labeling by the anti-rabbit IgG conjugate.

Immunoperoxidase (IP) for detecting the presence of CD4,

Table 1. Characteristics of the antibodies used in immunofluorescence and immunohistochemistry tests

\begin{tabular}{|c|c|c|c|c|c|}
\hline Specificity & $\begin{array}{l}\text { Antibody } \\
\text { designation }\end{array}$ & Cell expression & $\begin{array}{c}\text { Animal } \\
\text { origin } \\
\text { source }\end{array}$ & Dilution & L Laboratory \\
\hline Anti-ovine IgA & Anti-IgA & ICC IgA & Rabbit & $1: 40$ & BETHYL \\
\hline ne $\operatorname{Ig} G$ & Anti-IgG & ICC Ig & Rabbit & $1: 200$ & BETHYL \\
\hline Anti-ovine IgM & Anti-IgM & ICC IgM & Rabbit & $1: 160$ & BETHYL \\
\hline WC1 & CC15 & $\gamma / \delta$ lymphocytes & Mouse & $1: 400$ & SEROTEC \\
\hline CD4 & 17D1 & $\begin{array}{c}\text { Helper } \\
\text { Lymphocytes }\end{array}$ & Mouse & $1: 400$ & VMRD \\
\hline CD8 & CC63 & $\begin{array}{c}\text { Cytotoxic } \\
\text { Lymphocytes }\end{array}$ & Mouse & $1: 100$ & BIOSOURCE \\
\hline CD45RO & GC44A 3 & $\begin{array}{l}30 \% \text { of mononuclear } \\
\text { cells and granulocytes }\end{array}$ & Mouse & 1:500 & VMRD \\
\hline CD1b & CC14 & Dendritic cells & Mouse & $1: 100$ & BIOSOURCE \\
\hline CD14 & VPM 65 & $\begin{array}{c}\text { Macrophages, } \\
\text { monocytes }\end{array}$ & Mouse & $1: 30$ & BIOSOURCE \\
\hline
\end{tabular}

CD8, $\gamma / \delta$, WC1 lymphocytes, CD45Ro cells, macrophages (CD14), and dendritic cells (CD1b)

The slides with the four sections were hydrated in PBS for 10 minutes, and endogenous peroxidase was blocked with Perxoblock (Zymed, San Francisco, USA) for 45 seconds and with 10\% goat serum (Zymed, San Francisco, USA) overnight. Sections were incubated for 2 hours at room temperature with the primary antibodies prepared in mice, with the characteristics and at the dilutions shown in Table 1. Goat anti-mouse IgG-biotin complex (Zymed, San Francisco, USA) was applied for 30 minutes, and Streptavidin-Peroxidase complex was subsequently added (Zymed, San Francisco, USA) for 15 min.; DAB (Zymed, San Francisco, USA) was used as substrate and was administered until a 2- to 5 -minute reaction was observed, and contrast staining with hematoxylin was performed (Zymed, San Francisco, USA). The sec- tions were dehydrated by successive passages in alcohols, they were cleared with xylene and were mounted with resin. In the staining of the negative control section of the slides, the primary antibody was replaced with PBS, in order to continue with the technique previously described and to discriminate possible responses to endogenous peroxidases. Three five-minute washings with PBS were performed between each step.

\section{Cell count}

Prepuce and pelvic urethra cell counts were performed with both techniques in ten $40 \times 10$ fields, using an image analysis software (Image Pro Plus 4.5; Media Cybernetics, Silver Spring, USA). The cells present in the image projected by the program, with a surface area of $1.81 \times 10^{-2} \mathrm{~mm}^{2}$, were counted. Intraepithelial cells and those present in the mucosal connective tissue were counted, delimiting the area with the help of the software, and the result was expressed as the number of cells per $\mathrm{mm}^{2}$.

\section{Statistical analysis}

The mean of total positive IgA-, IgG-, and IgM-containing cells, CD4, CD8, WC1, CD45R0, CD1b and CD14 present in the prepuce and the urethra of the four animals and the number of labeled cells in the mucosal epithelium and connective tissue in the prepuce and the urethra was compared. The Kruskal-Wallis nonparametric method was used for these comparative analyses.

The graphs show the mean \pm standard error. The existence of a statistical difference with $\mathrm{p}<0.05$ was considered in all cases. The Kruskal-Wallis and Mann-Whitney tests were run with the SPSS 13 software for Windows (SPSS Corp., Chicago, USA).

\section{RESULTS}

In the histological review of the HE-stained sections, no elements suggesting an inflammatory lesion or lesions of any other origin were detected in any of the samples.

The results of the distribution study of the different cell types present in the prepuce and the urethra are summarized in Table 2 and Figure 1.

In the slides prepared for the observation of Ig-containing cells by fluorescence, the most abundant labeling corresponded to positive IgA-containing cells, which did not show significant differences between both tissues. In the urethra, scarce IgM-containing cells were observed, $8.3 \pm$ 32.2, and no IgG-containing cells were found, while in the prepuce, similar amounts of both cell types were found and in a significantly greater number, $140 \pm 45.2$ and $135 \pm 65$, than in the urethra $(\mathrm{p}<0.05)$, Table 2 .

Table 2. Average of IgA-, IgG-, and IgM- positive cells, CD4, CD8, CD45R0, WC1, CD14 and CD1b in the prepuce and the pelvic urethra

\begin{tabular}{lcc}
\hline & Prepuce & Pelvic urethra \\
\hline IgA & $295.5 \pm 67.8$ & $137.3 \pm 201$ \\
IgG & $135.5 \pm 65.0 \mathrm{a}$ & $0 \pm 0$ \\
IgM & $140.3 \pm 45.2 \mathrm{a}$ & $8.3 \pm 32.2$ \\
CD4 & $850.5 \pm 128.5 \mathrm{a}$ & $396.1 \pm 269$ \\
CD8 & $595.1 \pm 117.8$ & $539.3 \pm 278$ \\
CD45R0 & $1026 \pm 141.0 \mathrm{a}$ & $450.8 \pm 259$ \\
WC1 & $368.8 \pm 152.0 \mathrm{a}$ & $20.9 \pm 22.8$ \\
CD14 & $450 \pm 164.7 \mathrm{a}$ & $181.9 \pm 55.6$ \\
CD1b & $38 \pm 18.5 \mathrm{a}$ & $0 \pm 0$
\end{tabular}

a Significance of the comparison between the prepuce and the pelvic urethra $\mathrm{p}<0.05$. 


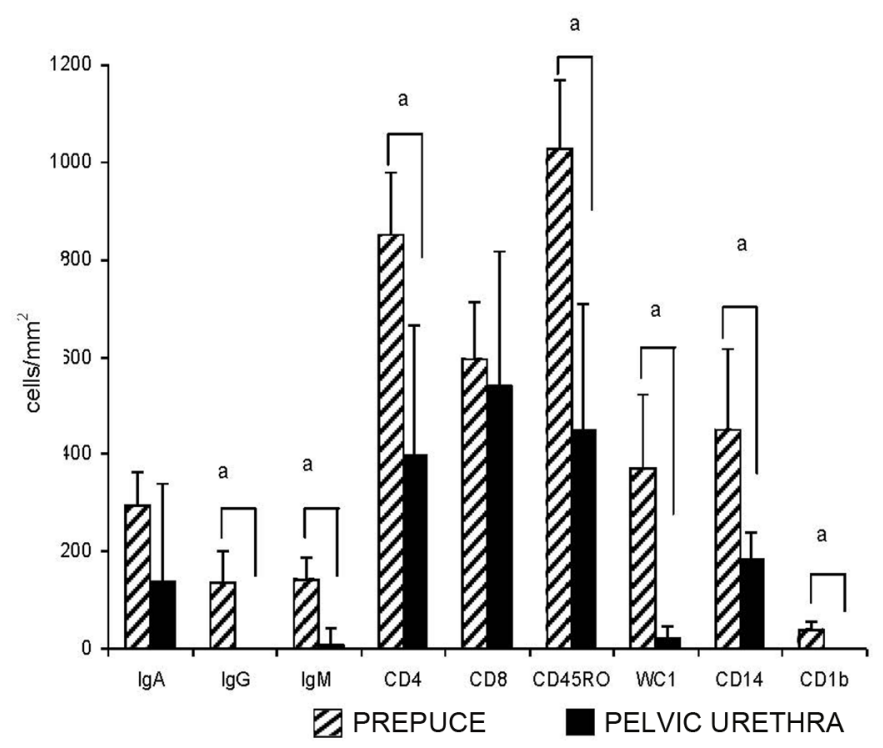

Fig.1. Number of IgA-, IgG-, and IgM- positive cells, CD4, CD8, CD45R0, WC1, CD14, and CD1b in the prepuce and the pelvic urethra.

Positive IgA-, IgG-, and IgM-containing cells were seen in the mucosal connective tissue in both organs; IgA-containing cells appeared in groups near the epithelia basement membrane in both mucosae (Fig.2a). In contrast, positive IgG- and IgM-containing cells were located distantly from the epithelium, deeper in the connective tissue (Fig.2b).

Significant differences were found in the total number of CD4, CD45R0, and TCR $\gamma \delta$ (WC1) lymphocytes, and in macrophages and dendritic cells between the mucosae of both organs. The mean values found in the prepuce were greater in all cases $(\mathrm{p}<0.05)$. No CD1b dendritic cells were found in the pelvic urethra, and they were scarce in the prepuce. No significant differences were found in CD8 cell populations in these tissues.

The comparative results of the count and distribution of intraepithelial cells and of those present in the mucosal connective tissues for the different cell types evaluated in the prepuce and the urethra are summarized in Table 3 and Figure 3.
Table 3. Distribution of CD4, CD8, CD45R0, WC1, CD14, and CD1b in the epithelium and the submucosa of the prepuce and pelvic urethra

\begin{tabular}{lccccc}
\hline & \multicolumn{2}{c}{ Prepuce } & & \multicolumn{2}{c}{ Pelvic urethra } \\
\cline { 2 - 3 } \cline { 5 - 6 } & Intraepithelial & Submucosal & & Intraepithelial & Submucosal \\
\hline CD4 & $90.9 \pm 52.3$ & $759.6 \pm 100.2^{\text {a }}$ & & $49.6 \pm 27$ & $346.5 \pm 135.5^{\text {a }}$ \\
CD8 & $298 \pm 74.5$ & $297.3 \pm 77.4$ & & $228 \pm 66.4$ & $311.7 \pm 142.2$ \\
CD45RO & $64,8 \pm 34.3$ & $961,6 \pm 152.3^{\text {a }}$ & & $189 \pm 72.4$ & $261.6 \pm 101.1$ \\
WC1 & $68 \pm 25.9$ & $300.8 \pm 133.4^{\text {a }}$ & & $2.8 \pm 4$ & $18.1 \pm 22.3^{\text {a }}$ \\
CD14 & $3.7 \pm 1.3$ & $447.2 \pm 163.6^{\text {a }}$ & & $0 \pm 0$ & $181.9 \pm 80.1^{\text {a }}$ \\
CD1b & $26.2 \pm 15.4$ & $12.1 \pm 5.4$ & & $0 \pm 0$ & $0 \pm 0$
\end{tabular}

${ }^{a}$ Intraepithelial and submucosal significance in the prepuce and the pelvic urethra $\mathrm{p}<0.05$.

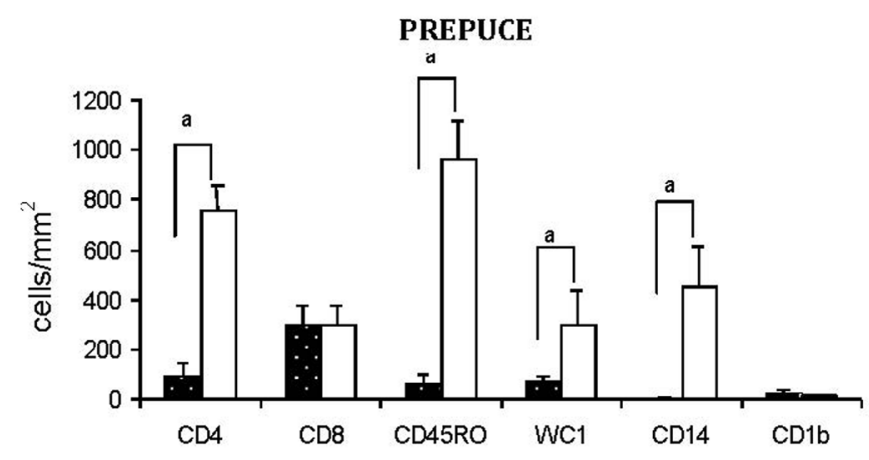

PFIUVIC. URFTHRA

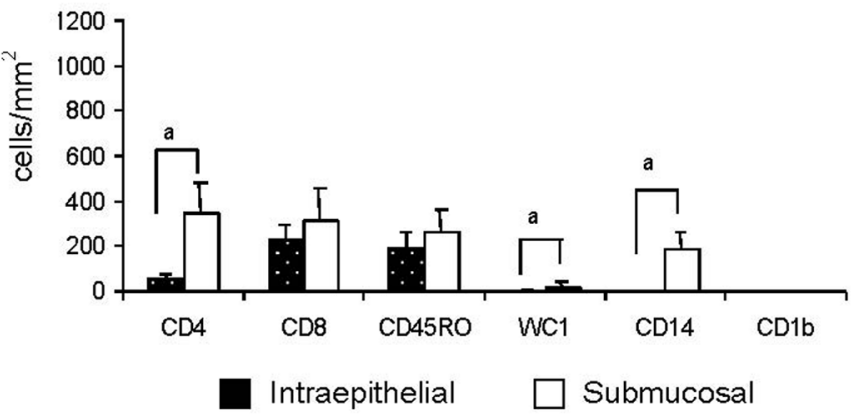

Fig.3. Number and distribution of IgA-, IgG-, and IgM- positive cells, CD4, CD8, CD45R0, WC1, CD14, and CD1b in the epithelium and the submucosa of the prepuce and pelvic urethra.

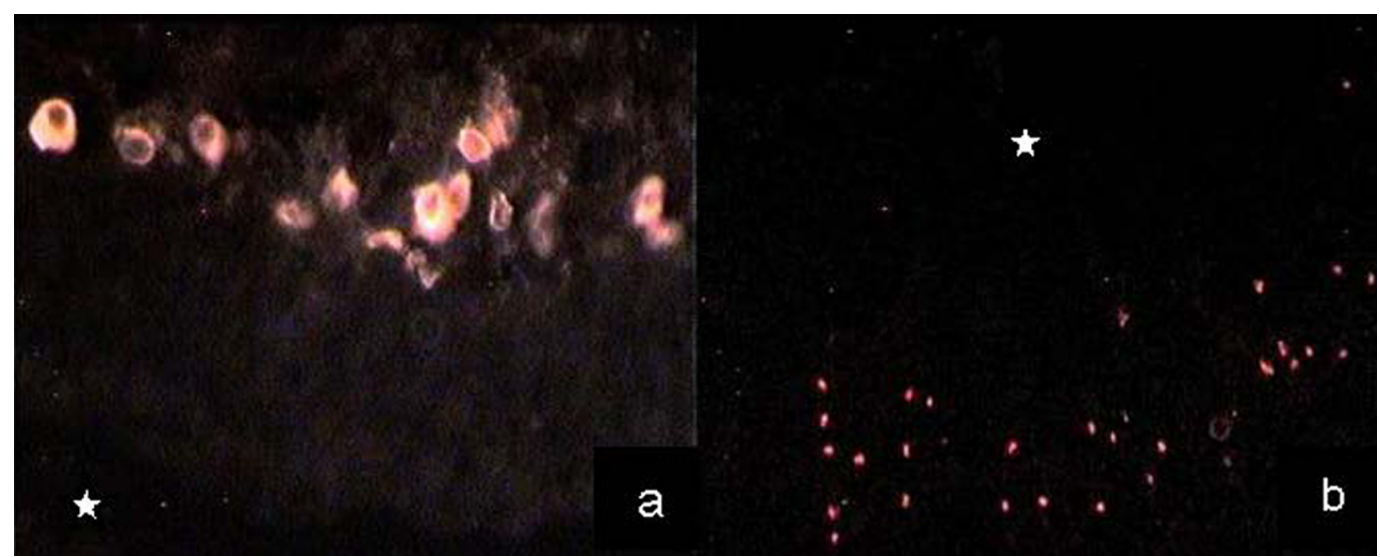

Fig.2. IgA- and IgG-positive cells in the pelvic urethra and the prepuce. (a) IgA-positive cells, some cells have abundant cytoplasm, suggesting plasma cells and other cells with scarce cytoplasm; they have a B lymphocyte-like morphology. IF, obj.40x. (b) IgG-positive cell in the preputial mucosa IF obj.10x. Indicates the surface of the epithelium. 

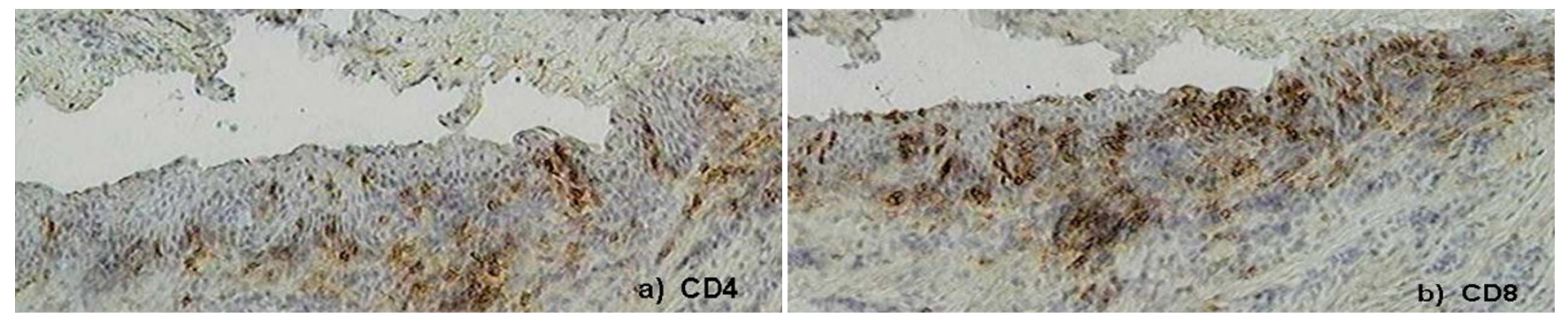

Fig.4. Aspects of the distribution of CD4 and CD8 lymphocytes in the pelvic urethra. (a) Labeling of CD4 lymphocytes. IP, obj.10x. (b) Labeling of CD8 lymphocytes in the urethral mucosa. Labeling is more abundant in the proximity and in the epithelium itself. IP, obj.10x.

The results of the differential count of intraepithelial cells and connective tissue cells show that there were significant differences in the distribution of CD4, TCR $\gamma \delta$ (WC1) lymphocytes and macrophages (CD14) between the prepuce and the urethra. TCR $\gamma \delta$ (WC1) lymphocytes in both
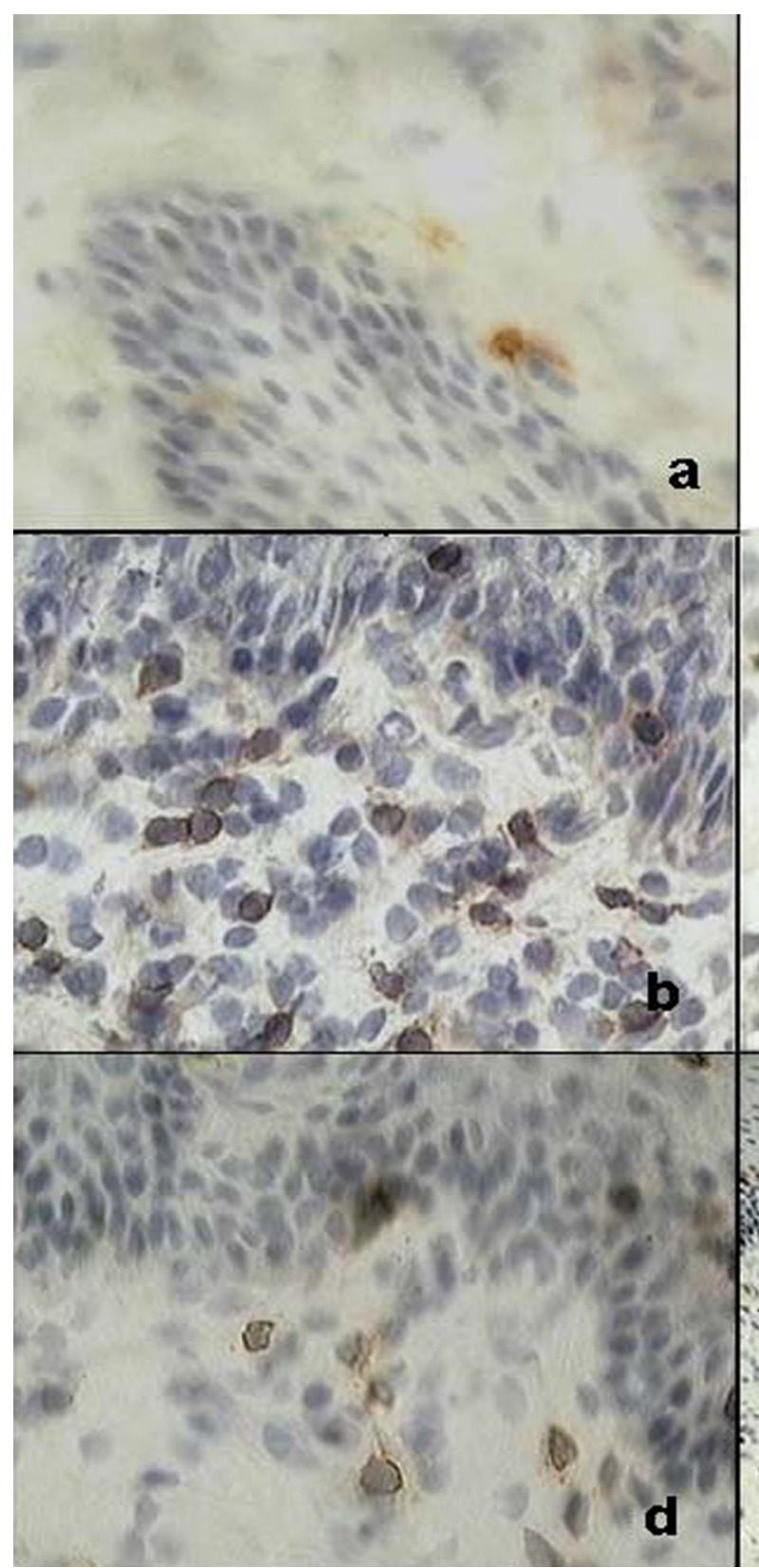

tissues were located intraepithelially or in the connective tissue near the basement membrane of the epithelium. In the urethra, no CD14 positive labeling was found in the epithelium, while in the prepuce, CD14 were scarce in the epithelium and in the connective tissue near the basement

Fig.5. Aspects of dendritic cells (CD1b) and CD4, CD8, and WC1 lymphocytes labeling in the prepuce. (a) Dendritic cell (CD1b) near a papilla of the preputial epithelium. IP, obj.40x. (b) CD4 lymphocytes in the preputial mucosa. Some of them are located in the basement membrane of the epithelium. IP, obj.40x. (c) TCR $\gamma \delta$ (WC1) lymphocytes in the preputial mucosa associated with, and inside of, the epithelium. IP, obj.40x. (d) CD8 lymphocytes in the preputial mucosa, in the connective tissue, and in the basement membrane of the epithelium. IP, obj.40x. (e) CD8 lymphocytes in the preputial mucosa, labeled cells are observed in the surface layers of the epithelium. IP, obj.10x.

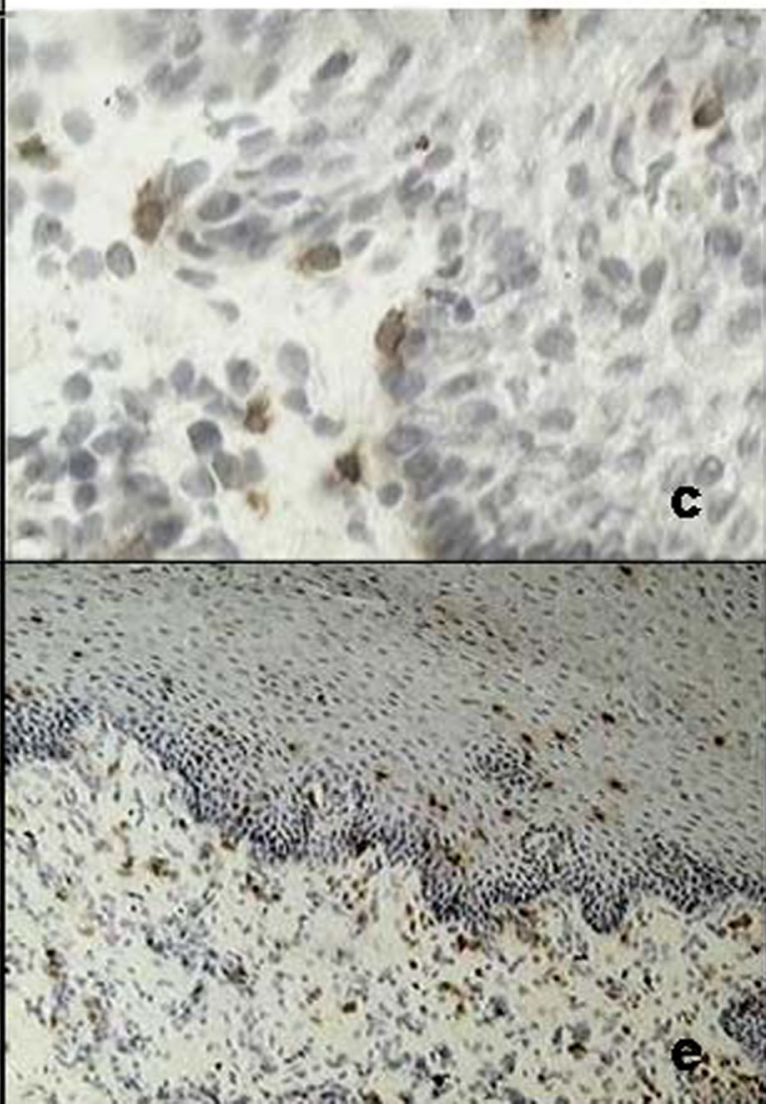


membrane and, in contrast, they were quite abundant in the deep connective tissue and in the proximity of mucosal papillae blood vessels. CD14 positive labeling was observed in the endothelia of preputial vessels.

CD8 lymphocytes had a similar distribution in both mucosae; intraepithelial CD8 were located more superficially than intraepithelial CD4 (Fig.4). CD45RO lymphocyte distribution in the prepuce showed a clear predominance of intraepithelial cells compared to those present in the connective tissue, in contrast, no differences were found in the distribution of these cells in the urethral mucosa. The few $\mathrm{CD} 1 \mathrm{~b}$ cells observed in the prepuce were found near basal epithelial cells (Fig.5a) or associated to lymphoid nodes, occasionally present in this part of the mucosa. Pictures of CD4, WC1, and CD8 lymphocyte labeling are presented (Fig.5b-e).

For each type of cell evaluated, the relationship between intraepithelially located cells and cells located in the connective tissue of the mucosa of both organs studied was established. CD4 lymphocytes were found in an average intraepithelial/connective tissue ratio of $10 / 1$ in the prepuce and 7/1 in the urethra, while CD8 lymphocytes had a 1/1 distribution in both mucosae. WC1 lymphocytes were present in a 5/1 ratio in both mucosae. The most notable and extreme observation occurred with CD45RO which had an intraepithelial/connective tissue ratio of $19 / 1$ in the prepuce and a 1/1 ratio in the pelvic urethra. CD14 and CD1b markers did not react in the urethral epithelium.

\section{DISCUSSION}

A greater number of positive IgA-containing cells than of IgM and IgG was observed in the prepuce; in contrast, Foster et al. (1988b) reported higher percentages of IgG-positive cells than of IgA- and IgM-positive cells in normal rams free of Brucella ovis and without testicular alterations. This remarkable difference in the same species may be explained by the animals' condition and characteristics, by the animals' age, by the presence of pathogens or previous or little apparent inflammatory processes, or may be due to variations in the drawing of samples. The preputial mucosa is structurally more similar to the skin than to a mucosa. However, the presence of IgG-containing cells in the skin may only be expected in dermatitis conditions, since the prevailing lymphocytes in the skin are type T lymphocytes (McKeever \& Reid 1987, Yirrell et al. 1989, Bos \& Kapsenberg 1993). Apparently, the lymphoid tissue and the epithelium itself do not show the same distribution in all preputial portions, and no lymphoid tissue organized in nodules is found in the fornix, as occurs in the mucocutaneous junction (Acosta-Dibarrat et al. 2003); this same variability has been reported in bulls (Flower et al. 1982).

In the urethra, only IgA-containing cells and IgM were found, as has been described in humans (Anderson \& Pundey 1999, Quayle et al. 1994), however, no positive IgA-containing cells are found in the mouse penile urethra.

Regarding the WC1 marker, a part of TCR $\gamma \delta$ lymphocytes express it on their surface; these are relatively abundant cells in ruminant blood, especially in young animals, and may be involved in the rapid release of Th1 cytokines (Pollock \& Welsh 2002). TCR $\gamma \delta$ constitute a first line of response of $\mathrm{T}$ cells in the recognition of cells altered by infection, inflammation, neoplastic changes, intoxication, thermal shock or radiations; therefore, their increase is associated with the occurrence of various inflammatory or infectious diseases (Baldwin et al. 2000). These cells produce keratinocyte growth factor and may be involved in epithelial repair processes (Van der Broek et al. 2005). The prepuce was the site with the greatest expression of WC1 lymphocytes. Studies conducted in ram skin (Van der Broek et al. 2005) using the same markers demonstrated amounts of WC1 similar to those observed in this case. In the normal skin, WC1 cells were more abundant than CD4 and CD8 (Van der Broek et al. 2005), conversely, the number of CD4 and CD8 was higher in the prepuce.

The function of the leukocyte common antigen, CD45, is to modulate the $\mathrm{T}$ lymphocyte activation signal transduction. Its CD45RO isoform occurs in CD4 and CD8 T cells and in the memory subclasses (Bembridge et al. 1993). This isoform is also expressed in monocytes, granulocytes, and in mononuclear cells presenting WC1, TCR $\gamma \delta$, CD4- and CD8-, but it is not expressed by B lymphocytes (Bembridge et al. 1995). This isoform is particularly abundant in the lymphocytes that reside in the mucosa; in the intestinal lamina propria they may represent $93 \%$, while they represent $30 \%$ of circulating blood lymphocytes (Stephen \& Hiroshi 1993). This marker prevailed in both mucosae studied.

A greater amount of WC1 lymphocytes and macrophages was observed in the preputial mucosa connective tissue than in that of the urethra, which explains that CD45RO, which marks lymphocytes and macrophages, was also present in a greater relative and absolute number in the prepuce than in the urethra.

The intraepithelial lymphocytes demonstrated in the prepuce and the urethra were mainly CD8 and WC1. The presence of CD4 and CD8 lymphocytes has also been described in the urethral mucosa in mice (Quayle et al. 1994) and similar observations have been made in human urethra, which is consistent with neutrophil and $\mathrm{T}$ and $\mathrm{B}$ cell infiltration (Anderson \& Pudney 1999). As seen in the digestive tract mucosa (Kelsall \& Strober 1999), intraepithelial lymphocytes in the urethra and the prepuce are mainly CD8. A relatively high number of intraepithelial lymphocytes were WC1 ( $\mathrm{T} \gamma \delta$ lymphocytes), especially in the prepuce. Intraepithelial lymphocytes are likely to recognize a limited variety of microbial and cellular antigens and may be involved in epithelial monitoring and repair processes, rather than in immune response processes (Boismenu 1994).

The CD1b marker is a surface glycoprotein found in cells that present lipid and glycolipid antigens to T cells (Porcelli et al. 1998, Rhind 2001). 60 to $90 \%$ of dendritic cells present in the lymph nodes and the dermis express CD1b (Dutia \& Hopkins 1991). Dendritic cells are considered the main antigen-presenting cells for TCR $\gamma \delta$ lymphocytes (Rhind 2001). The number of CD1b observed in the preputial mucosa was similar to that reported for normal ovine skin (Van der Broek et al. 2005). On the other hand, the abs- 
cence of this marker in the urethral mucosa is an observation consistent with what has been reported for the urethra in humans and mice (Quayle et al. 1994).

The CD14 marker is usually found in the surface of macrophages capable of recognizing LPS of Gram bacteria, either alone or associated with proteins (Wright et al. 1990). The observation of endothelial labeling with CD14 in the prepuce may be due to the fact that LPS stimulates its expression in the endothelia, which increases the activity of endothelial cells in the production of TNF- $\alpha$ and IL-6 (Dai et al. 2002). Quayle et al. (1994), report the presence of numerous macrophages in the urethral mucosa of mouse, similarly to what has been observed in this study for ovines.

\section{CONCLUSION}

The presence of antigen-presenting cells, macrophages, and dendritic cells, as well as of CD4, CD8 TCR $\gamma \delta$ (WC1) lymphocytes, IgM-containing cells, IgG, and IgA, and CD45RO cells indicates that the preputial and urethral mucosae of rams have the cell components necessary to act as inductive sites and immune response sites of the mucosae.

Acknowledgements.- This study was supported by the project PAPIIT IN 206101 UNAM and F-PROMEP-38/Rev-03. We are grateful to Amanda de Souza da Motta of the Microbiology, Immunology and Parasitology Department, Institute of Basic Health Sciences, Federal University of Rio Grande do Sul for the translation of the abstract to the Portuguese.

\section{REFERENCES}

Acosta-Dibarrat J.P., Garrido F.G., Díaz L.A.C. \& Tórtora P.J.L. 2003. Análisis histológico y de distribución de linfocitos CD4 y CD8, en linfonódulos asociados a la mucosa prepucial del ovino. Memorias del XII Congreso Nacional Producción Ovina, Tulancingo, Hidalgo, México. (Resumen)

Acosta-Dibarrat J., Díaz-Aparicio E., Arellano-Reynoso B., Tenorio-Gutiérrez V. \& Tórtora-Pérez J. 2006. Experimental induction of epididymitis in sheep, by intra-urethral inoculation of Actinobacillus seminis: a bacteriological, serological, and histopathological study. Téc. Pecu. Mex. 44:257-267.

Acosta-Dibarrat J., Díaz-Aparicio E., Tenorio-Gutiérrez V., Suárez-Güemes F. \& Tórtora-Pérez J. 2007. Determination of pathological changes in the reproductive tract, IgG, IgM and IgA antibodies in blood, seminal plasma and smegma of rams inoculated with Actinobacillus seminis. J. Anim. Vet. Advances 6:105-113.

Anderson D.J. \& Pudney J. 1999. Human Male Genital Tract Immunity and Experimental Models, p.1411-1422. In: Ogra P.L., Mestecky J., Lamm M.E., Strober W., Bienenstock J. \& McGhee, J.R. (Eds), Mucosal immunology. $2^{\text {nd }}$ ed. Academic Press, San Diego.

Baldwin C.L., Sathiyaseelan T., Rocchi M. \& McKeever D. 2000. Rapid changes occur in the percentage of circulating bovine $\mathrm{WC} 1+\gamma \delta \mathrm{Th} 1$ cells. Res. Vet. Sci. 69:176-180.

Bembridge G.P., MacHugh N.D., McKeever D., Awino E., Sopp P., Collins R.A., Gelder K.I. \& Howard C.J. 1995. CD45RO expression on bovine T cells: relation to biological function. Immunology. 86:537-544.

Bembridge G.P., Parsons K.R., Sopp P., MacHugh N.D. \& Howard C.J. 1993. Comparison of monoclonal antibodies with potential specificity for restricted isoforms of the leukocyte common antigen (CD45R). Vet. Immunol. Immunopathol. 39:129-136.

Boismenu R. \& Havran W.L. 1994. Modulation of epithelial cell growth by intraepithelial gamma delta T cell. Science 266:1253-1255.

Bos J.D. \& Kapsenberg M.L. 1993. The skin immune system: progress in cutaneous biology. Immunol. Today 14:75-78.
Campero C.M., Ladds P.W., Hoffmann D. \& De'ath G. 1989. Immunoglobulin containing cells in normal and inflamed accessory sex glands of bull. Aust. Vet. J. 66:137-140.

Campero C.M., Hirst R.G., Ladds P.W., Vaughan J.A., Emery D.L. \& Watson D.L. 1990. Measurement of antibody in serum and genital fluids of bulls by ELISA after vaccination and challenge with Tritrichomonas foetus. Aust. Vet. J. 67:175-178.

Corbeil L.B. \& BonDurant R.H. 2001. Immunity to bovine reproductive infection. Vet. Clin. North. Am. Food Anim. Pract. 17:567-583.

Dai L., Gong J., Luo Y. \& Liu C. 2002. Expression of CD (14) protein in liver sinusoidal endothelial cells during endotoxemia. Zhonghua Gan Zang Bing Za Zhi. 10:93-95. (Abstract)

Dutia B.M. \& Hopkins J. 1991. Analysis of the CD1 cluster in sheep. Vet. Immunol. Immunopathol. 27:189-194.

Flower P.J., Ladds P.W., Thomas A.D. \& Watson D.L. 1982. An immunopathologic study of de Bovine Prepuce. Vet. Pathol. 20:189-202.

Foster R.A., Ladds P.W., Husband A.J. \& Hoffmann D. 1988a. Immunoglobulins and immunoglobulin-containing cells in the reproductive tract of rams naturally infected with Brucella ovis. Aust. Vet. J. 65:37-40.

Foster R.A., Ladds P.W., Hoffmann D. \& Husband A.J. 1988b. Immunoglobulins and immunoglobulin-containing cells in the reproductive tract of normal rams. Aust. Vet. J. 65:16-20.

Jansen B.C. 1983. The epidemiology of bacterial infection of the genitalia in rams. Onderstepoort J. Vet. Res. 50:275-282.

Kelsall B. \& Strober W. 1999. Gut-Associated Lymphoid Tissue, p.293317. In: Ogra P.L., Mestecky J., Lamm M.E., Strober W., Bienenstock J. \& McGhee J.R. (Eds), Mucosal immunology. $2^{\text {nd }}$ ed. Academic Press, San Diego.

McKeever D.J. \& Reid H.W. 1987. The response of the supramammary lymph node of the sheep to secondary infection with orf virus. Vet. Microbiol. 14:3-13.

Moldoveanu Z., Huang W.Q., Kulhavy R., Plate M.S. \& Mestecky J. 2005. Human Male Genital Tract Secretions: Both Mucosal and Systemic Immune Compartments Contribute to the Humoral Immunity. J. Immunol. 175:4127-4136.

Plant J.W., Eamens G.J. \& Seaman J.T. 1986. Serological, bacteriological and pathological changes in rams following different routes of exposure to Brucella ovis. Aust. Vet. J. 63:409-412.

Pollock J.M. \& Welsh M.D. 2002. The WC1 $1^{+} \delta \gamma$ T cell population in cattle: a possible role in resistance to intracellular infection. Vet. Immunol. Immunopathol. 89:105-114.

Porcelli S.A., Segelke B.W., Sugita M., Wilson I.A. \& Brenner M.B. 1998. The CD1 family of lipid antigen-presenting molecules. Immunol. Today 19:362-368.

Quayle A.J., Pudney J., Muñoz D.E. \& Anderson D.J. 1994. Characterization of T lymphocytes and antigen-presenting cells in the murine male urethra. Biol. Reprod. 51:809-820.

Rhind S.M. 2001. CD1-The pathology Perspective. Vet. Pathol. 38:611-619.

Stephen P.J. \& Hiroshi K. 1999. Gastrointestinal Lamina Propria T Cells, p.381-393. In: Ogra P.L., Mestecky J., Lamm, M.E. Strober W. Bienenstock, J. \& McGhee J.R. (Eds), Mucosal Immunology. $2^{\text {nd }}$ ed. Academic Press, San Diego.

Van der Broek A.H.M., Huntley J.F., MacKellar A., Machell J., Taylor M.A. \& Miller H.R.P. 2005. Characterization of lesional infiltrates of dendritic cells and T cell subtypes during primary infestation of sheep whit Psoroptes ovis, the sheep scab mite. Vet. Immunol. Immunophatol. 105:141150.

Yirrell D.L., Reid H.W., Norval M. \& Howie S.E.M. 1989. Immune response of lambs to experimental infection with orf virus. Vet. Immunol. Immunopathol. 22:321-332.

Wright S.D., Ramos R.A., Tobias P.S., Ulevitch R.J. \& Mathison J.C. 1990. CD14 a receptor for complex of lipopolysaccharide (LPS) and LPS binding protein. Science 249:1431-1433. 